\title{
CH31 - Developing improved varieties of faba bean
}

\author{
Authors: Fouad Maalouf ${ }^{*}$, Seid Ahmed ${ }^{2}$ and Somanagouda Patil ${ }^{2}$ \\ ${ }^{I}$ International Centre for Agricultural Research in the Dry Areas (ICARDA), Terbol, Lebanon. \\ ${ }_{2}^{2}$ International Centre for Agricultural Research in the Dry Areas (ICARDA), Rabat, Morocco. \\ *Corresponding author. Email: f.maalouf@cgiar.org
}

\begin{abstract}
s:
Faba bean is an important cool-season food legume crop grown under different cropping systems for dry grain and green pods, animal feed and a green-manure worldwide. It contributes to reduce carbon footprint of cereal based agricultural production systems. The present chapter book aim to present the major research achievements in faba bean which include identification of faba bean lines tolerant to heat, drought, herbicide tolerance, broomrape resistance, disease resistance, and high nitrogen fixation. Sources Glyphosate tolerance and Imazethapyr and Metribuzin tolerance identified in faba bean. Donors for multiple disease resistance were identified and shared with National Agriculture Centre for further use in the breeding program. Diverse released varieties with resistance to chocolate spot were released in Ethiopia combining ICARDA lines with local landraces. Different varieties with orobanche resistance were released in Ethiopia, Egypt and Tunisia, which will help to recuperate the threaten area in target countries. The faba bean are increased in Sudan with the released of improved varieties adapted to warmer environments that the traditional area in Nile Delta- Egypt.
\end{abstract}

Keywords: Faba bean, heat, drought, herbicide tolerance, orobanche resistance 


\section{Contents}

1. Introduction

2. Heat tolerance

3. Drought tolerance

4. Herbicide tolerance

5. Breeding for resistance to foliar diseases

6. Breeding for broomrape resistance

7. Biological nitrogen fixation

8. Major achievements

a. Partial orobanche resistance varieties

b. Heat tolerance varieties

9. Future trends in research

10. References 


\section{Introduction}

Faba bean (Vicia faba L.) is the third most important cool-season food legume crop grown under rainfed and irrigated conditions in more than 55 countries. It is grown under different cropping systems as dry grains, green pods, animal feed and a green-manure worldwide on 2.4 million ha with 4.4 million tons of production in 2014 (Fig. 1). Faba bean production has been shown to contribute in reducing carbon footprint of cereal based agricultural production systems through its ability in fixing nitrogen that can be used by the succeeding cereal crop and by breaking the cycle of biotic stresses (Jensen et al. 2010).

In North Africa, area under faba bean cultivation a remains stagnant during last past 5 decades, but its production has increased from 405,000 tons in 1961-65 to 605,000 tons in 2011-2014. North Africa remains in short supply with annual import of 0.44 million tons mainly from Australia and Canada (FAOSTAT 2016). In North Africa, the major faba bean consuming countries are Egypt, Morocco and Sudan, which are importing 0.34 MT with a value of 320 million USD and West Asia region imports 93589 tons with a value of 65 million USD in 2013 (FAOSTAT 2016).

In East Africa, Ethiopia is the major consumer and producer of faba bean. Area under faba bean grains has increased from 348,400 ha in 1993-95 to 471,700 ha in 2011-14 with yield increase from $1 \mathrm{t} /$ ha to $1.9 \mathrm{t} / \mathrm{ha}$ respectively. Productivity of improved varieties is very high $(3.5 \mathrm{t} / \mathrm{ha})$ compared to the country average yield (1.8 t/ha). Although many countries in North Africa and Nile valley region imports faba bean. Ethiopia exported 0.04 MT of faba bean with total 25 million USD in 2013 (FAOSTAT 2016).

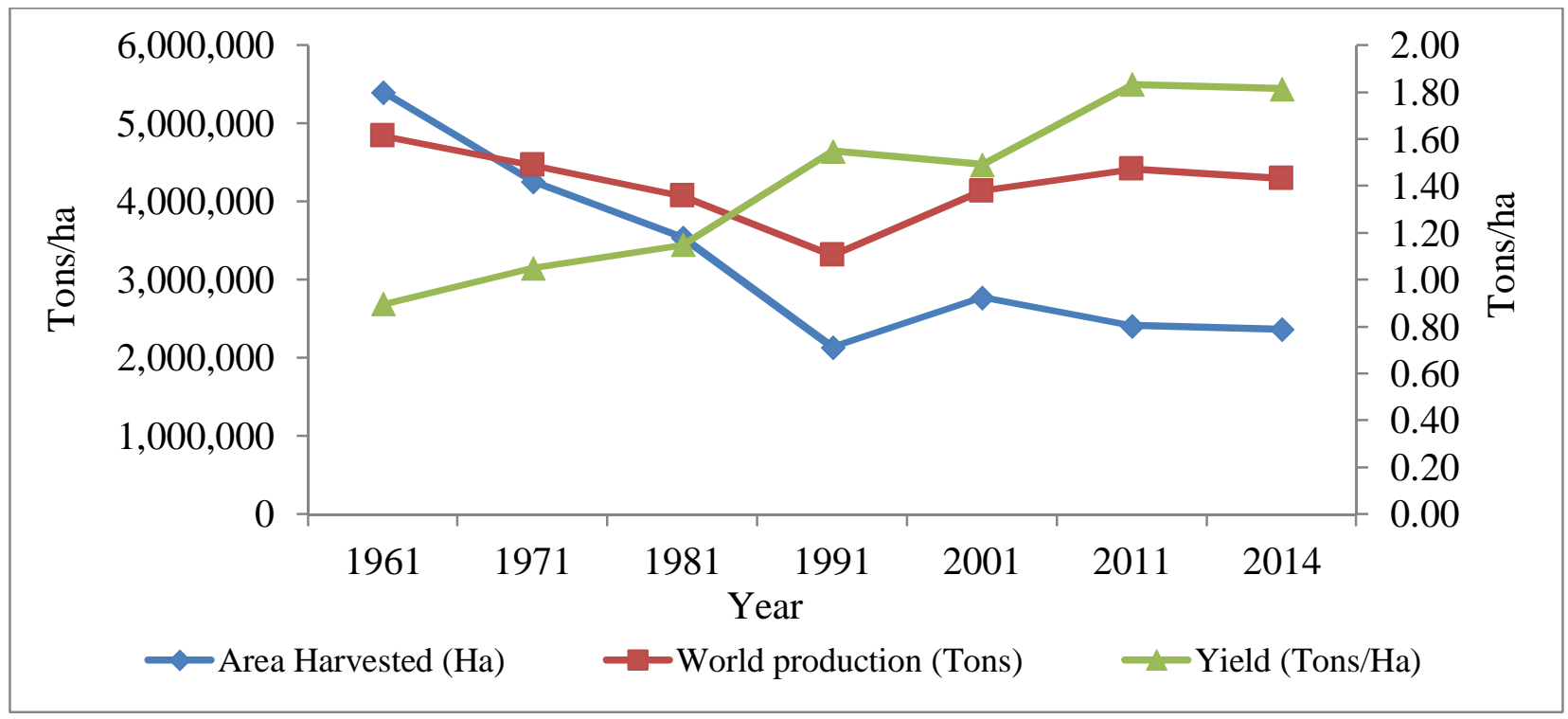

Fig. 1: Trend of faba bean area, production and productivity in world (FAOSTAT 2016). 
The productivity of faba bean is decreasing due to various biotic and abiotic stresses. The major biotic stresses are parasitic weeds (Orobanche and Phelipanche spp), foliar diseases, mainly chocolate spot (Botrytis fabae), rust (Oromyces fabae), ascochyta blight (Ascochyta fabae), powdery mildew (Microsphaera penicillata var. ludens) and faba bean leaf gall ((Olpidium viciae (Kusano)) and soil born diseases (Fusarium root rots), in West Asia, North Africa and East Africa (El-Sayed et al. 2011, Hanounik 1980; Maalouf et al. 2011; Tivoli et al. 2006, Abebe et al. 2013; Hailu et al. 2014). In middle Egypt, faba bean necrotic yellow virus devastated the crop in 1992, which has led to the complete disappearance of all types of faba bean landraces and cultivars (Katul et al. 1993; Makkouk et al. 1994). In many production regions in the Mediterranean basin, the crop is seldom if ever irrigated and generally relies on rainfall for its growth and development. Variation in the amount and distribution of rainfall is generally the major reason for variability in seed yield of faba bean (Siddique et al. 2001). Heat stress is increasingly becoming a serious constraint to faba bean production in certain regions due to the shift from cooler, long season environments to warm, short season environments (Gaur et al. 2015). The area under faba bean in Egypt was reduced from 113000 ha in 2001 to 46000 ha in 2014 while in to Sudan where the weather is hotter and the season is shorter the area increases from 50000 ha in 2001 to 76000 ha in 2014 (FAOSTAT 2016). This is in addition to climatic change where dry areas in becoming hotter. Heat sensitivity in grain legumes can reduce grain yield, quality and leads to restricted geographic adaptation. Soil acidity and salinity are the common problems that limit production of faba bean in Ethiopia (Asefa et al. 2010). Soil acidity can adversely affect survival, growth, nitrogen-fixation efficiency of rhizobia and formation of symbiotic association between rhizobia and their host legumes (Graham 1992; Zahran 1999).

The purpose of this review is to present major research achievements in faba bean, which include identification of sources of tolerant to heat and drought, herbicide tolerance, broomrape resistance, disease resistance, and high nitrogen fixation.

\section{Heat tolerance}

Heat, drought, water logging and frost are the major abiotic stresses affecting the faba bean productivity in North and East Africa. In West Asia, terminal drought, frost, and heat. Heat stress is particularly harmful at the reproductive stage of faba bean plants. In fact, high sensitivity of pollen to heat stress is shown in legumes and other plant species (Prasad et al. 2006; Wang et al. 2006). The seed-filling period is also very sensitive to elevated temperatures (Egli et al. 2005). The duration from seedling emergence to flowering and maturity of faba bean has been shown to be governed by the photo-thermal duration. The optimum temperature for flowering of faba bean is $22-23^{\circ} \mathrm{C}$ (Patrick and Stoddard 2010). Sub-optimal temperatures and photoperiods during early plant growth delay flowering. Ellis et al. (1988) noted marked differences in the rate of seedling emergence and progress to flowering of six faba bean genotypes in response to supra-optimal temperatures. Ellis et al. (1990) demonstrated that various faba bean genotypes show similar sensitivity of the rate of progress towards flowering to temperature regime but variable sensitivity to photoperiod. 
Extreme heat is the major threat to faba bean production in south Egypt, Sudan, and the Ethiopian lowlands. Artificially induced terminal heat stress can significantly reduce yield and the yield components of faba bean genotypes (Abdelmula and Abuanja 2007). This adverse effect could be attributed mainly to high temperature during the vegetation period which checked growth and led to the development of a small, short-stemmed crop with few branches and pods. Abdelmula and Abuanja (2007) concluded that the genotype C.52/1/1/1 could be used to improve heat tolerance in faba bean and make it possible to extend production of faba bean in the non-traditional areas of Sudan. Moreover, the traits that exhibited strong and positive association with yield could be used as selection criteria for improving faba bean under heat stress conditions.

\section{Drought tolerance}

Drought, an interval of water deficiency leading to a significant reduction in yield, is widely considered to be the most important environmental constraint to crop productivity (Borlaug and Dowswell 2005). Variation in the amount and distribution of rainfall is generally considered the major reason for variability in grain yield of faba bean (Bond et al. 1994; Siddique et al. 2001).

Terminal drought is one important constraint to faba bean production, particularly in Ethiopia and Morocco where it is largely grown under rainfed conditions. Identification of early maturing genotypes adapted to drylands with a short rainfed period and use of supplemental irrigation would have a significant impact on final yield. Although genotypic variation in the response of faba bean to drought has been documented (Abdelmula et al. 1999; Amede et al. 1999), the development of drought-tolerant cultivars is essential to improve its yield stability. Plant breeders evaluate and select breeding material empirically for adaptation to drought under experiment conditions based on grain yield at drought-prone sites. Maalouf et al. (2015) reported significant differences among faba bean genotypes under different water regimes without any significant interactions. FLIP06010FB was the highest yielding and most stable among the tested genotypes across different environments. Days to flowering and maturity were positively correlated with grain yield.

Some studies have reported physiological traits associated with drought, such as carbon isotope discrimination, leaf temperature and stomatal conductance (Khan et al. 2007). However, the physiological processes associated with adaptation to drought are not as well understood as those for some other crop species. To breed drought-tolerant cultivars, it is imperative to identify the specific physiological traits that improve adaptation to water-limited environments (Subbarao et al. 1995). So far, progress using this approach has been slow mainly due to the lack of an efficient screening technique (Wery et al. 1994; Stoddard et al. 2006). The physiological status of the canopy may be measured via spectral reflectance, which is a practical method of integrating physiological trait selection within crop improvement and research programs (Peñuelas et al. 1995a, 1995b; Osborne et al. 2002; Babar et al. 2006a). In faba bean the spectral indices, Structure Insensitive Pigment Index (SIPI) and Normalized Phenophytinization Index (NPQI) were found to positively correlate with grain yield and could be therefore used for selection under droughtprone environments (Maalouf et al. 2015). 


\section{Herbicide tolerance}

Non parasitic and parasitic weeds are the major production constraints in faba bean because of slow initial growth and being poor competitor to weeds. Mechanical or manual weeding is considered to be the only management options in faba bean because of highly sensitive to postemergence herbicides. Pre-emergence herbicides are effective in controlling weeds at early stage of seedling growth, but weeds germinating after crop emergence become dominant in the field and cause substantial yield losses (Solh and Pala 1990). In addition, faba bean is also heavily infested by parasitic weeds, Orobanche spp, in North and East Africa. Resistance to orobanche in current varieties is partial and consequently there is a need to develop integrated management with herbicide tolerance such as low dosage of Glyphosate, which may affect the crop in some cases. Therefore, to supplement the partial resistance to orobanche, there is a need to screen faba bean lines for high dosage of Glyphosate or to other effective herbicides such as Imazethapyr and Metribuzin.

At International Center of Agricultural Research in the Dry Area (ICARDA), 289 mutant lines of faba bean were screened against high dosage of Glyphosate, resulting in identification of two lines Mu38 and Mu418 as tolerant to $1600 \mathrm{~g}$ a.i./ha (Balech et al. 2016). Similarly, 300 faba bean lines were screened against various post-emergence herbicides with different modes of action like Metribuzin, Imazethapyr and Oxyfluorfen during 2014/2015 season. During 2015/2016 season, 45 genotypes selected as tolerant to moderate tolerance for Metribuzin (photo-synthesis inhibitor) and Imazethapyr (amino acid synthesis inhibitor). In general, the sensitivity for Imazethapyr was higher as compared to that for Metribuzin. Of the 45 tested genotypes, two genotypes (Lattakia3 and Superagualdulce) were found tolerant to Metribuzin (Fig. 2)

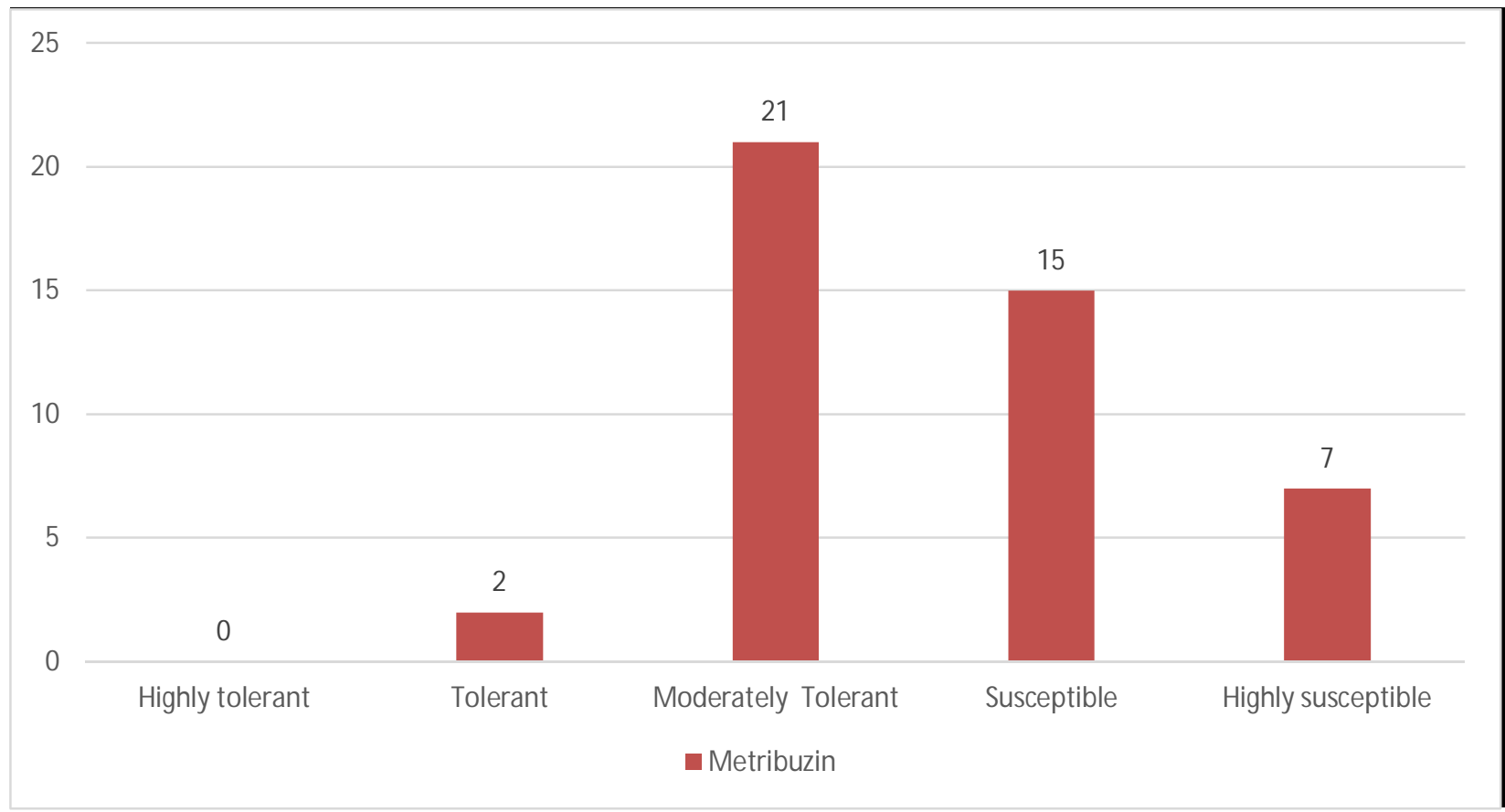

Fig. 2: Grouping of herbicides based on herbicide tolerance level 


\section{Breeding for resistance to foliar diseases}

Agronomical practices such as crop rotation, delayed planting date, fungicide applications and use of certified seeds may provide partial protection against the foliar diseases. However, the most effective and eco-friendly disease control method is through developing resistant cultivars. The effective resistant sources for ascochyta blight and chocolate spot were identified at ICARDA (Robertson 1984; Hanounik and Robertson 1988, 1989). These lines wereused by ICARDA and National Agricultural Research Systems (NARS), to develop breeding lines with good levels of resistance with high yield potential. As a result, varieties were released in Australia, Canada, China, Egypt, Ethiopia, and Spain (Hanounik and Robertson 1989; Sillero et al. 2001; Trvoli et al. 2006; Redden et al. 2008; Villegas-Fernández et al. 2009; Sillero et al. 2010; Rubiales et al 2012; Maalouf et al. 2013; Temesgen et al. 2015). Although most breeding programs are focusing on developing resistant genotypes for a single disease of economic importance, efforts have recently been directed to develop faba bean lines with multiple disease resistance (Villegas-Fernández et al. 2011).

Recently, ICARDA has identified new sources for multiple disease resistance for ascochyta blight, chocolate spot and rust for further use in breeding programs. The main area for the sources of resistance to chocolate spot and ascochyta blight (Maalouf et al. 2016a) was Fertile Crescent coincides with the centre of origin of this crop (Cubero 1973). More than 180 new sources for resistance to chocolate spot, ascochyta blight and rust were identified at ICARDA in 'sick plots' of heavy soils infested at Lattakia, Syria by a mixture of the most virulent pathogens collected in Syria. Lines with combined resistance have been developed at ICARDA and sent to different NARS to observe the response of the resistant lines to different races in varying environments. Several varieties released in Ethiopia with a high-level resistance to chocolate spot, derived from the ICARDA breeding program, were released by the Ethiopian Institute of Agricultural Research (EIAR).

Through collaborative research, EIAR researchers have released several high-yielding faba bean varieties through direct selection from germplasm supplied by ICARDA, or by transferring good levels of resistance from ICARDA germplasm into locally-adapted varieties. Among the faba bean varieties released with partial resistance to chocolate spot are 'Moti' (ILB 4432 X Kuse-227-33), 'Gebelcho' (ILB 4726 X 'Tesfa'), Obsie (ILB 4427 X CS20DK) and 'Walki' (ILB 4615 $\mathrm{X}$ Bulga 70). The variety 'Walki' was developed for water-logged areas and is gaining popularity in the central highlands of Ethiopia, and more recently the varieties 'Gora' (Didea (EH01048-1: ILB2717-1x R878-1) and Didea (EH01048-1: ILB2717-1x R878-1) are both two released varieties in Ethiopia with combined chocolate spot resistance and large seed type.

\section{Breeding for broomrape resistance}

Faba bean cultivation is strongly hampered by the occurrence of broomrape, Orobanche spp. in Middle East, and North and East Africa. Faba bean is infested by various broomrape types 
(Orobanche spp), among the most deleterious species, Orobanche crenata Forsk is considered indigenous in the Mediterranean basin (Rubiales et al. 2006). In Morocco, the infestation of Orobanche in faba bean progressed from $12 \%$ in 1981 to $51 \%$ in 2003 growing season. The estimated average yield losses due to Orobanche in Morocco was 37.4\% in 1998. Orobanche infestation in Algeria spreads over $60 \%$ of the area in the middle coast and is continuing its spread from the middle zone towards the west. In Tunisia, the main Orobanche species include $O$. crenata, $O$. foetida and $O$. ramosa affecting $7.1 \%$ area of total food legumes growing areas (AbuIrmaileh and Labrada 2016). Faba bean was abandoned in Upper Egypt mainly due to Orobanche infestation and only recently faba bean has regained some of its area, mainly due to availability of Orobanche resistant varieties. $O$. crenata is also affecting the productivity of faba bean in Ethiopia and North part of Sudan.

Breeding for Orobanche resistance is difficult in faba bean, due to limited sources of resistance, complex nature of the resistance mechanism and low heritability (Rubiales et al. 2006, 2009; Pérez de- Luque et al. 2010). Radwan et al. (1988a) found that parasitic weeds varied in their influence on host genotype and host-parasite relationship and were largely dependent on environmental conditions. The levels of resistance to Orobanche in faba bean can be characterized as necrosis of host cells that prevent Orobanche intrusion either before or just after penetration in the host root, or a barrier developing in the host root after the formation of a small tubercle (Pérezde-Luque et al. 2007). Despite breeding difficulties, there have been significant successes in developing tolerant/resistant varieties and breeding materials in Egypt, Spain, Italy, Morocco and ICARDA (Elia 1964; Cubero 1973; Kasasian 1973; Nassib et al. 1978, 1982; Fischbeck et al. 1986; Perrino et al. 1988; Radwan et al. 1988b; Cubero et al. 1992; Khalil et al. 2004) using the

main source of Orobanche resistance line F402 identified by Egyptian researchers in early 1970s (Nassib et al. 1978) and some minor sources available in different countries.

\section{Biological nitrogen fixation}

The increasing concern regarding enough food to meet the growing human population demand has been reinforcing the importance of sustainable intensification of agricultural practices which includes legume crops for their ability of biological nitrogen fixation. Abiotic stresses, such as heat, drought, salinity and low soil $\mathrm{pH}$, are the major limiting factors to nitrogen-fixation ability of faba bean (Küçük and Kivanç 2008). Soil salinity is a significant problem facing agricultural production in many areas of the world and soil infertility in these areas is often due to the presence of large concentrations of salt. Most leguminous plants require a neutral or slightly acidic soil for growth, especially when they depend on symbiotic $\mathrm{N}_{2}$ fixation and as well more sensitive to salinity than their rhizobia counterparts and consequently, the symbiosis being more sensitive to salt stress than free-living rhizobia (Zahran, 1999).

Soil acidity is among the common problems that limits the production of faba bean in Ethiopia (Asefa et al. 2010). Acid soil infertility is caused by toxicities of hydrogen ion, aluminum, and manganese, and deficiency of calcium, molybdenum and phosphorus (Graham, 1992; Chen et al. 1993). Soil acidity can adversely affect survival, growth and nitrogen-fixation efficiency of the 
rhizobia, formation of symbiotic association between rhizobia and their host legumes (Chen et al. 1991; Graham, 1992; Zahran, 1999). Generally, Rhizobium strains vary markedly in their acid tolerance and ability to nodulate their host legume on acid soil (Zahran 1999). Several studies indicated that some rhizobia strains are acid tolerant when grown in acidic laboratory medium (Chen et al. 1993; Del Papa et al. 1999; Asefa et al. 2010; Jida and Assefa 2011).

The use of pink-pigmented facultative methylotrophic bacteria (PPFMs) may increase nitrogen fixation which benefits not only the crop itself but the followed crop. ICARDA and ARC-Egypt evaluated the response of 25 faba bean genotypes under natural conditions, treatment with improved rhizobia and with PPFMs. The study showed that plant nitrogen content increased from 238.6 to 284.2 and $360.6 \mathrm{mg} /$ plant when inoculated with improved rhizobia only and combined treatment of rhizobia and PPFMs respectively. Two faba bean accessions 45/018/F8/7307/06A and Sakha1 showed the higher plant nitrogen content comparing to other genotypes (Maalouf et al. 2016b)

\section{Major achievements}

\section{a. Partial orobanche resistance varieties}

ICARDA has developed faba bean lines with different levels of tolerance and resistance to Orobanche for the parasite population existing in Syria (Khalil et al. 2004) and tested in different location with NARS partners (Maalouf et al. 2011). The program shifted to Douyet-Morocco and Sids-Egypt after the Syrian war broke out in 2012. Negative correlation between grain yield and number Orobanche shoot $(-0.46, \mathrm{p}<0.001)$ across locations and season which indicates that infection of Orobanche reduces yield of faba bean genotypes. Among 194 tested genotypes, 49 lines were found partially resistant to Orobanche adapted to diverse locations (Table 1).

Table 1: Orobanche resistant lines identified in diverse locations

\begin{tabular}{|l|l|l|l|}
\hline Number & pedigree & Number & pedigree \\
\hline $11 \mathrm{~A} 15 \mathrm{OFS}-1$ & WRB 1-5 X F7/8983/05 & $11248-3$ & $10901-1 / 2010 / \mathrm{Giza}-402$ \\
\hline $11 \mathrm{~A} 15 \mathrm{OFS}-2$ & Fam 2-1-1 X F7/8984/05 & $11248-4$ & $10901-1 / 2010 / \mathrm{Giza}-402$ \\
\hline $10931-2$ & $10170-2 / 2010 / \mathrm{HBP} / \mathrm{DSO} / 2000$ & $11248-6$ & $10901-1 / 2010 / \mathrm{Giza}-402$ \\
\hline $10931-3$ & $10170-2 / 2010 / \mathrm{HBP} / \mathrm{DSO} / 2000$ & $11248-7$ & $10901-1 / 2010 / \mathrm{Giza}-402$ \\
\hline $10931-5$ & $10170-2 / 2010 / \mathrm{HBP} / \mathrm{DSO} / 2000$ & $11256-3$ & $10170-2 / 2010 / \mathrm{HBP} / \mathrm{DSO} / 2000$ \\
\hline $10931-7$ & $10170-2 / 2010 / \mathrm{HBP} / \mathrm{DSO} / 2000$ & $11268-2$ & $10338-2 / 2010 / \mathrm{HBP} / \mathrm{ESO} / 2000$ \\
\hline $10945-4$ & $9883-3 / 2010 / \mathrm{HBP} / \mathrm{DSO} / 2000$ & $11314-2$ & $10591-3 / 2010 / \mathrm{HBP} / \mathrm{SO} / 2000$ \\
\hline $10953-3$ & $10706-3 / 2010 / \mathrm{S} 98013(\mathrm{DC})$ & $11389-4$ & $10158-1 / 2010 / \mathrm{HBP} / \mathrm{DSO} / 2000$ \\
\hline $11072-1$ & $9151-1 / 2010 / \mathrm{HBP} / \mathrm{DSO} / 2000$ & $11392-2$ & $9019-6 / 2010 / \mathrm{HBP} / \mathrm{DSO} / 2000$ \\
\hline $11248-1$ & $10901-1 / 2010 / \mathrm{Giza}-4$ & $11414-2$ & $9289-6 / 2010 / \mathrm{HBP} / \mathrm{DSO} / 2000$ \\
\hline $11418-2$ & $10456-1 / 2010 / \mathrm{HBP} / \mathrm{ESO} / 2000$ & $11543-7$ & $10919-1 / 2010 / \mathrm{Giza}-429$ \\
\hline $11419-2$ & $9883-3 / 2010 / \mathrm{HBP} / \mathrm{DSO} / 2000$ & $11544-1$ & $9303-2 / 2010 / \mathrm{HBP} / \mathrm{DSO} / 2000$ \\
\hline $11420-3$ & $9845-4 / 2010 / \mathrm{HBP} / \mathrm{DSO} / 2000$ & $11544-4$ & $9303-2 / 2010 / \mathrm{HBP} / \mathrm{DSO} / 2000$ \\
\hline $11426-1$ & $9029-2 / 2010 / \mathrm{HBP} / \mathrm{DSO} / 2000$ & $11549-1$ & $9738-1 / 2010 / \mathrm{HBP} / \mathrm{DSO} / 2000$ \\
\hline
\end{tabular}




\begin{tabular}{|l|l|l|l|}
\hline $11432-2$ & $10130-4 / 2010 / \mathrm{HBP} / \mathrm{DSO} / 2000$ & $11549-2$ & $9738-1 / 2010 / \mathrm{HBP} / \mathrm{DSO} / 2000$ \\
\hline $11432-3$ & $10130-4 / 2010 / \mathrm{HBP} / \mathrm{DSO} / 2000$ & $11555-4$ & $10170-2 / 2010 / \mathrm{HBP} / \mathrm{DSO} / 2000$ \\
\hline $11510-4$ & $9608-1 / 2010 / \mathrm{HBP} / \mathrm{DSO} / 2000$ & $11567-3$ & $9160-10 / 2010 / \mathrm{HBP} / \mathrm{DSO} / 2000$ \\
\hline $11535-1$ & $10129-4 / 2010 / \mathrm{HBP} / \mathrm{DSO} / 2000$ & $11599-1$ & $9402-1 / 2010 / \mathrm{HBP} / \mathrm{DSO} / 2000$ \\
\hline $11539-5$ & $10559-3 / 2010 / \mathrm{HBP} / \mathrm{ESO} / 2000$ & $11626-1$ & $9414-2 / 2010 / \mathrm{HBP} / \mathrm{DSO} / 2000$ \\
\hline $11543-3$ & $10919-1 / 2010 / \mathrm{Giza}-429$ & $11719-3$ & $9411-3 / 2010 / \mathrm{HBP} / \mathrm{DSO} / 2000$ \\
\hline
\end{tabular}

Faba bean lines with resistance to Orobanche, disease resistance and heat tolerance were released in different countries as the results of the joint effort of ICARDA breeding program and NARS partners in different locations: Giza843 and Misr3 in Egypt, Hashbenge (ILB4358) in Ethiopia and Najah and Chourok in Tunisia. Under EU-IFAD project integrated management options comprising resistant varieties, Misr3 and Giza-843 and chemical control of Orobanche were dissiminated during 2013-2015. Organic fertilizers were also added to the package to improve soil fertility and carbon sink.. This technology intervention has led to $25 \%$ increase in faba bean production with enhanced soil fertility. It was found that the recommended technology package increased farmers' grain yield by $256 \mathrm{~kg} \mathrm{ha}^{-1}$ and reduced production costs by 350 USD $\mathrm{ha}^{-1}$. The result was an increase in net revenue by $550 \mathrm{USD} \mathrm{ha}^{-1}$. From the samples of 695 surveyed farmers, $46 \%$ were using new varieties and parts of the technology package and $14 \%$ were using the full technology package

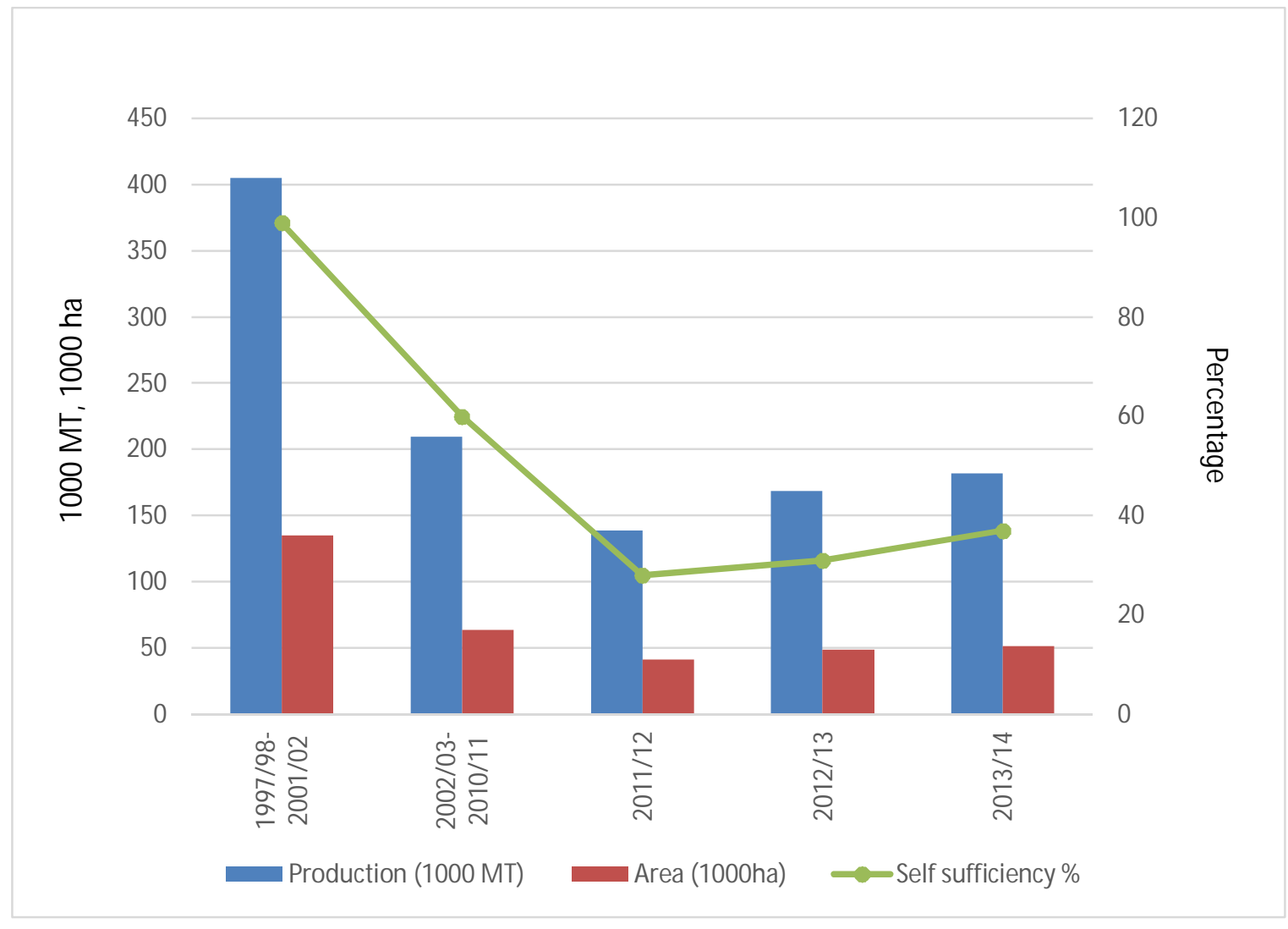


Fig. 2: Trends of faba bean production and cultivation along with the self-sufficiency rate in Egypt.

\section{b. Heat tolerance varieties}

In our conditions, heat stress with temperature above $32^{\circ} \mathrm{C}$ affect the faba bean crop severely specially by reducing the percentage of germinated seeds, increase in occurrence of abnormal seedlings; early flowering; degeneration of nodules affecting the nitrogen fixation efficiency; reduction of plant biomass. Heat stress during the reproductive phase affects pollen viability, fertilization, pod set and seed development leading to abscission of flowers and pods and substantial losses in grain yield. Genetic variation for heat tolerance has been identified in faba bean.

Pollen viability of faba bean tested lines varied from 0 to $50 \%$ under $32^{\circ} \mathrm{C}$ and from 0 to $33 \%$ under. Significant differences were found among evaluated genotypes for all studies traits indicating wide range of genetic variability. Heat stress can cause significant reduction in pollen germination and yield components of the majority of studied accessions. Principle Component Analysis revealed that at $35^{\circ} \mathrm{C}$, yield component and pollen viability explained $58 \%$ of the total variation. Based on these results, seven accessions were selected for being tolerant to heat stress. Seven accessions with higher rate of pollen viability under $35^{\circ} \mathrm{C}$ and higher values of pod number and seed number per plant were identified (IG11743, IG11843, VF351, VF420, VF522, VF626, and INRA1631). Improved lines for heat tolerance evaluated under Sudanese conditions were identified (Table 2) and will be further evaluated in famers fields.

Table 2: accession with higher degree of tolerance to heat

\begin{tabular}{|l|l|}
\hline Accession name & Pedigree \\
\hline Sel TerWS11-81/2012 & S 88134-14-1-4- 33018-2/TR2010/ WS11-81 \\
\hline Sel TerWS11-106/2012 & BPL 5061-33005/TR2010- WS11-106 \\
\hline Sel TerWI11-18-2/2012 & S 88094-8-1-32114-1/TR2010/ WI11-18-2 \\
\hline Sel TerWI11-164/2012 & S 88096-6-2-32219/TR2010/ WI11-164 \\
\hline Sel TerWI11-181-1/2012 & Giza 4-32087-1/TR2010/ WI11-181-1 \\
\hline Sel TerWI11-244-1/2012 & ILB445-32122-1/TR2010/ WI11-244-1 \\
\hline Sel TerWI11-249-1/2012 & S 88094-8-2-32334/TR2010/ WI11-249-1 \\
\hline Sel TerWI11-312-2/2012 & Selection from Hudaiba- Fam Hu-15/ WI11-312-2 \\
\hline
\end{tabular}

The improved faba bean varieties (Hudeiba-93 and Basabeer) developed during the Nile Valley projects in collaboration with ICARDA in 1993 and 2000 respectively and Eddamer in 2012 during EU-IFAD project were brought to farmers in North part of Sudan where heat stress is the major constraints. The area of faba bean cultivation increased from 20,000 in 1993 to 75,000 ha in 2014 and the production increased from approximately 30,000 tons in 1993 to 154,000 tons in 2014 (Fig. 6). 


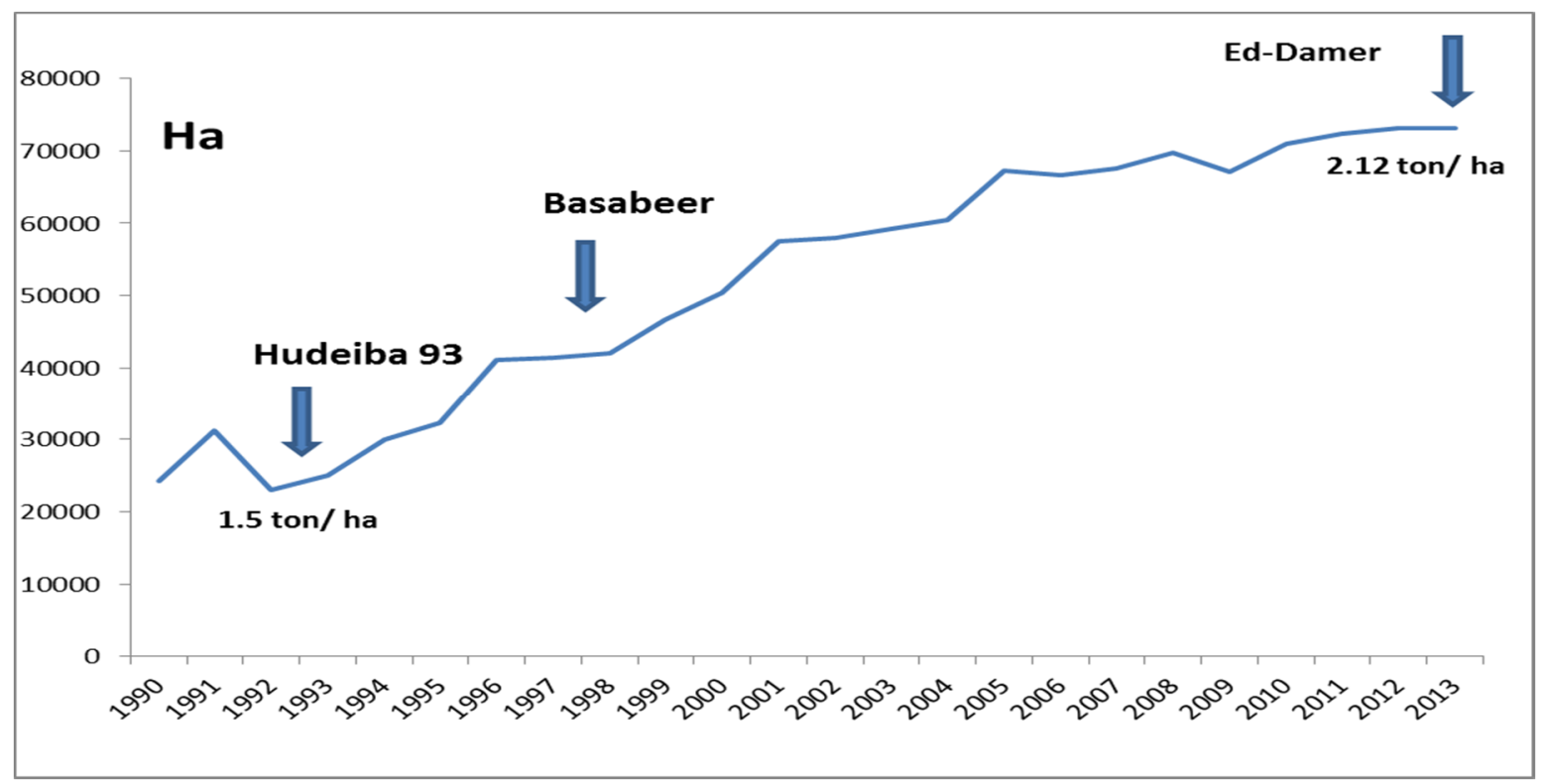

Fig. 6: Trends of faba bean area and productivity in Sudan (FAOSTAT, 2016)

\section{Future trends in research:}

To enhance farm profitability through adoption of improved faba bean technologies in North Africa and Nile Valley regions, there is a need to develop high yielding nutritious varieties with multiple pest resistant/tolerant suitable for different cropping systems prevalent in different agroecological zones in North and East Africa. There is need to develop climate smart varieties which can tolerate stress of drought, heat, waterlogged and acid soils. Development of improved germplasm tolerant to faba bean necrotic yellow virus for middle Egypt, new gall disease in Ethiopia and Lexus in North Africa need immediate research attention. Develop herbicide tolerant faba bean germplasm to solve the problem of weeds in North Africa and integrate the crop in cereals mono-cropping. Include salinity, acid soils; faba bean for water and nutrient efficiency; faba bean for animal feed etc.

The breeding efforts are relatively slow due to the nature of the mechanism of resistance for foliar diseases, orobanche resistance, major abiotic stresses (heat and drought) and herbicide resistance. To accelerate breeding cycles, there is a need to use the emerging biotechnological tools, such as marker assisted selection, which have not been widely adopted despite significant achievements on quantitative trait loci (QTL) studies associated with Ascochyta blight, rust and chocolate spot resistance and orobanche resistance (Torres et al. 2010) and the development of consensus maps in faba bean (Satovic et al. 2013; Webb et al. 2015). The knowledge generated in the model legumes Medicago truncatula and Lotus japonicus will help to overcome these gaps and speed the process (Dita et al. 2006; Rispail et al. 2010). Gene expression, including large-scale approaches and functional analyses performed in the models will help to understand plant/pathogen interactions. Although relevant progress is made in tissue culture, genetic transformation of faba bean (Hanafy et al. 2013), that can be used appropriate genes responsible 
to diverse stresses tolerance/resistance, specially introduction of glyphosate tolerance in the faba bean cultivars

\section{References}

Abdelmula A.A. and Abuanja I.K. (2007), Genotypic responses, yield stability, and association between characters among some of Sudanese faba bean (Vicia faba L.) genotypes under heat stress. Conference on International Agricultural Tropentag Research for Development University of Kassel-Witzenhausen and University of Göttingen, pp, 1-7.

Abdelmula A.A. Link W. Von Kittlitz E. and Stelling D. (1999), Heterosis and inheritance of drought tolerance in faba bean (Vicia faba L). Plant Breed. 118, 485-490.

Abebe T. Meles K. Nega Y. Beyene H. and Kebede A. (2013), Interaction between broomrape (orobanche crenata) and resistance faba bean genotypes (Vicia faba L) in Trigray region of Ethiopia. Can. J. Plant Prod. 1(3), 104-109.

Abu-Irmaileh B.E. and Labrada R. (2016), http://www.fao.org/agriculture/crops/ thematicsitemap/theme/ biodiversity/weeds/ (Accessed on 15 November 2016).

Amede T. Kittlitz E.V. and Schubert S. (1999), Differential drought responses of faba bean (Vicia faba L) inbred lines. J. Agron. Crop Sci. 183, 35-45.

Asefa K. Assefa F. and Prabu P.C. (2010), Characterization of acid and salt tolerant rhizobial strains isolated from faba bean fields of Wollo, Northern Ethiopia. J. Agric. Sci. Technol. 12, 365376.

Babar M.A. Reynolds M.P. Van Ginkel M. Klatt A.R. Raun W.R. and Stone M.L. (2006), Spectral reflectance indices as potential indirect selection criteria for wheat yield under irrigation. Crop Sci. $46,578-588$

Balech R. Singh S. and Maalouf F. (2016), Identification of faba bean lines tolerant to high dosage of Glyphosate. In: International Conference on Pulses, Marrakesh, Morocco, 18-20 April, 2016. Poster presentation Theme 2. PP33.

Bond D.A. Jellis G.J. Rowland G.G. Le Guen, J. Robertson L.D. Khalil S.A. and Li-Juan L. (1994), Present status and future strategy in breeding faba beans (Vicia faba L.) for resistance to biotic and abiotic stresses. Euphytica 73, 151-166.

Borlaug N. and Dowswell C.R. (2005), Feeding a world of ten billion people: a $21^{\text {st }}$ century challenge. In: Tuberosa R., Phillips R.L., Gale M.D. (Eds.), In the Wake of the Double Helix: From the Green Revolution to the Gene Revolution, 27-31 May 2003, Bologna, Italy. Avenue Media, Bologna, Italy.

Chen H. Richardson A.E. Cartner E., Diordjevic M.A. Roughley, R.J. and Rolfe B.G. (1991), Construction of an acid tolerant Rhizobium leguminosarum biovar trifolii strain with enhanced capacity for nitrogen fixation. Appl. Environ. Microbio. 57, 2005-2011 
Chen H. Cartner E. and Rolfe B.G. (1993). Involvement of genes on a megaplasmid in the acid tolerant phenotype of Rhizobium leguminosarum biovar trifolii. Appl. Environ. Microbio. 59, 1058-1064.

Cubero J.I. (1973), Evolutionary trends in Vicia faba. Theoretical Appl. Gene. 43(2), 59-65.

Cubero J.I. Moreno M.T. and Hernandez L. (1992), A faba bean (Vicia faba L.) cultivar resistant to broomrape (Orobanche crenata Forsk.). In: P. Plancquaert (Ed.), Proceedings of the 1st European conference on grain legumes, Angers, France, 1-3 June 1992 (pp. 41-42). Paris, France: L'association Europeenne des Proteagineux.

Del Papa M.F. Balaque L.J. Sowinski S.C. Wegner C. Segudo E. Abrca F.M. Toro N. Nichaul K. Puhler A. Aguilar O.M. Martinez-Drets G. and Lagares A. (1999), Isolation and characterization of alfalfa nodulating rhizobia present in acidic soils of central Argentina and Uruguay. Appl. Environ. Microbio. 65, 1420-1427.

Dita M.A. Rispail N. Prats E. Rubiales D. and Singh K.B. (2006), Biotechnology approaches to overcome biotic and abiotic stress constraints in legumes. Euphytica 147, 1-24.

Egli D.B. TeKrony D.M. Heitholt J.J. and Rupe J. (2005), Air temperature during seed filling and soybean seed germination and vigor. Crop Sci. 45, 1329-1335

Elia M. (1964), Indagini preliminari sulla resistenza varietale della Fava (Vicia faba) all'orobanche, Phytopathol. Mediter, 3, 31-32. In Kasasian, L. Orobanche spp. PANS.

Ellis R.H. Roberts E.H. and Summerfield R.J. (1988), Variation in the optimum temperature for rates of seedling emergence and progress towards flowering amongst six genotypes of faba bean (Vicia faba). Ann. Bot. 62, 119-126.

Ellis R.H. Summerfield R.J. and Roberts E.H. (1990), Flowering in faba bean: genotypic differences in photoperiod sensitivity, similarities in temperature sensitivity, and implications for screening germplasm. Ann. Bot. 65, 129-138

El-Sayed A. Sahar R.Z. El-Shennawy M. and Ismail A.I. (2011), Fungicidal management of chocolate spot of faba bean and assessment of yield losses due to the disease. Annals of Agricultural Science. 56, 27-35.

FAOSTAT (2016), http://www.fao.org/faostat/en/\#data/QC

Fischbeck G. Abdalla M.M.F. Metwally A.A. and Darwish D.S. (1986), Variation of Vicia faba L. genotypes and populations of Orobanche crenata Forsk. In: Proc. $2^{\text {nd }}$ Agron. Conf. vol. 2, Alex. Egypt, pp, 489-514. Fischer and Turner 1978.

Gaur P. Saminen S. Krishnamurthy L. Kumar S. Ghanem M. Beebe S. Rao I. Chaturvedi S. Basu P. Nayyar H. Jayalakshmi V. Babbar A. and Varshney R. (2015), High temperature tolerance in grain legumes. Legume Perspectives. 7, 23-24

Graham P.H. (1992), Stress tolerance in Rhizobium and Bradyrhizobium, and nodulation under adverse soil conditions. Canadian J. Microbio. 38, 475-484. 
Hailu E. Getaneh G. Sefera T. Tadesse N. Bitew B. Boydom A. Kassa D. and Temesgen T. (2014), Faba bean gall; a new threat for faba bean (Vicia faba) production in Ethiopia. Adv. Crop Sci. Technol. doi:10.4172/2329-8863.1000144.

Hanafy M.S. El-Banna A. Schumacher H.M. Jacobsen H.J. and Hassan F. (2013), Enhanced tolerance to drought and salt stresses in transgenic faba bean (Vicia faba L.) plants by heterologous expression of the PR10a gene from potato Plant Cell Rep DOI 10.1007/s00299-013-1401-x

Hanounik S.B. (1980), Effect of chemical treatments and host genotypes on disease severity/yield relationships of Ascochyta blight in faba beans. FABIS Newslett. 2, 50.

Hanounik S.B. and Robertson L.D. (1988), New sources of resistance

Hanounik S.B. and Robertson L.D. (1989), Resistance in Vicia faba germplasm to blight caused by Ascochyta fabae. Plant Dis. 73, 202-205.

Jensen E.S. Peoples M.B. and Hauggaard-Nielsen H. (2010), Faba bean in cropping systems. Field Crops Res. 115, 203-216

Jida M. and Assefa F. (2011), Phenotypic and plant growth promoting characteristics of Rhizobium leguminosarum bv. viciae from lentil growing areas of Ethiopia. African J. Microbio. Res. 5, 41334142 .

Katul L. Vetten H.J. Maiss E. Makkouk K.M. Lesemann D.E. and Casper R. (1993), Characterization and serology of virus-like particles associated with faba bean necrotic yellows. Ann. Appl. Bio. 123, 629-647.

Khalil S. Kharrat M. Malhotra R.S. Saxena M.C. and Erskine W. (2004), Breeding faba bean for Orobanche resistance. In: Dahan R. and El-Mourid, M. (Eds.), International Management of Orobanche in Food Legumes in the Near East and North Africa. Proceedings of the Expert Consultation on IPM for Orobanche in Food Legume Systems in the Near East and North Africa. Rabat, Morocco, pp. 1-18.

Khan H.R. Link W. Hocking T.J. and Stoddard F.L. (2007), Evaluation of physiological traits for improving drought tolerance in faba bean (Vicia faba L.). Plant Soil 292, 205-217.

Küçük C. and Kıvanç M. (2008), Preliminary characterization of Rhizobium strains isolated from chickpea nodules. African J. Biotechnol. 7, 772-775

Maalouf F. Ahmed S. Shaaban K. Bassam B. Nawar F. Singh M. and Amri A. (2016a), New faba bean germplasm with multiple resistances to ascochyta blight, chocolate spot and rust diseases. Euphytica. DOI 10.1007/s10681-016-1726-y

Maalouf F. Hamwieh A. Abou Taleb H. and Abdul Rehman R. (2016b), Studies on influence of pink-pigmented facultative methylotrophic bacteria PPFMs and Rhizobium inoculation on BNF in Faba bean and Chickpea genotypes. CRP PHASE1-2012-2016-REVIEW MEETING- 
Reflections on four years of research aimed to improve the lives of smallholder farmers. Presentation and poster abstracts 03 to 07 October 2016. Pp, 33

Maalouf F. Khalil S. Ahmed S. Akintunde A.N. Kharrat M. Hajjar S. and El Shama'a K. (2011) ,Yield stability of faba bean lines under diverse broomrape prone production environments. Field Crop Res. 124, 288-294

Maalouf F. Nawar M. Hamwieh A. Amri A. Zong X. Bao S. and Yang T. (2013) Faba bean In: Singh M. Upadhyaya H.D. Singh Bisht I. (Eds) Genetic and Genomic Resources of Grain Legume Improvement. Elsevier Insight. ISBN: 978-0-12-397. Pp 113-136

Maalouf, F. Nachit M. Ghanem Edmond M. and Singh M. (2015) Evaluation of faba bean breeding lines for spectral indices, yield traits and yield stability under diverse environments. Crop Pasture Sci. 66, 1012-1023. http://dx.doi.org/10.1071/CP14226

Makkouk K.M. Rizkallah L. Madkour M. El-Sherbeiny M. Kumari S.G. Amriti A.W. and Solh M. (1994), Survey of faba bean (Vicia faba L.) for viruses in Egypt. Phytopathologia Mediterranea, 33, 207-211.

Nassib A.M. Ibrahim A.A. and Khalil S.A. (1982), Breeding for resistance to Orobanche. In: Hawtin, G., Webb, C. (Eds.), Faba bean Improvement, Martinus Nijhoff. The Hague, The Netherlands, pp. 199-206.

Nassib A.M. Ibrahim A.A. and Saber H.A. 1978. Broomrape (Orobanche crenata) resistance in broad beans. In: Proceedings of a Workshop on Seed Legumes, ICARDA, Aleppo, Syria, pp. 133135 .

Osborne S.L. Schepers J.S. Francis D.D. and Schlemmer M.R. (2002), Use of spectral radiance to estimate in-seasonBYandGYin nitrogen- and water-stressed corn. Crop Sci. 42, 165-171. doi: $10.2135 /$ cropsci2002.0165

Patrick J.W. and Stoddard F.L. (2010), Physiology of flowering and grain filling in faba bean. Field. Crop. Res. 115, 234-242.

Peñuelas J. Baret F. and Filella I. (1995a), Semi-empirical indices to assess carotenoids/chlorophyll $a$ ratio from leaf spectral reflectance. Photosynthetica 31, 221-230

Peñuelas J. Filella I. Lloret P. Munoz F.J. and Vilajeliu M. (1995b) Reflectance assessment of plant mite attack on apple trees. Int. J. Remote Sensing 16, 2727-2733

Pérez-de-Luque A. Eizenberg H. Grenz J.H. Sillero J.C. Ávila C.M. Sauerborn J. and Rubiales D. (2010), Broomrape management in faba bean. Field Crops Res. 115, 319-328.

Pérez-de-Luque A. Lozano M.D. Moreno M.T. Testillano P.S. and Rubiales D. (2007), Resistance to broomrape (Orobanche crenata) in faba bean (Vicia faba): cell wall changes associated with pre-haustorial defensive mechanisms. Ann. Appl. Biol. 151, 89-98.

Perrino P. Pace M.S. and Polignano G.B. (1988), Evaluation for tolerance to broomrape in a germplasm collection of Vicia faba. FABIS Newslett. 20, 40-44. 
Prasad P. Boote K. Allen L. Sheehy J. and Thomas J. (2006), Species, ecotype and cultivar differences in spikelet fertility and harvest index of rice in response to high temperature stress. Field Crops Res. 95, 398-411. 10.1016/j.fcr.2005.04.008

Radwan M.S. Abdalla M.M.F. Fishbeck G. Metwally A.A. and Darwish D.S. (1988a), Variation in reaction of faba bean lines to different accessions of Orobanche crenat Forsk. Plant Breeding $101,208-221$.

Radwan M.S. Abdalla M.M.F. Fishbeck G. Metwally A.A. and Darwish D.S. (1988b), Selection in faba bean for tolerance to broomrape (Orobanche crenata Forsk). Plant Breeding 100, 289-298.

Redden R. van Leur J. Zong X. Bao S. Yujioa L. Paull J. and Leonforte T. (2008), Evaluation and utilisation of pea and faba bean germplasm from China. In Global issues, paddock action. Unkovich M. (Eds.) Global Issues Paddock Action. Proceedings of the 14th Australian Agronomy Conference. September 2008, Adelaide South Australia. Australian Society of Agronomy. www.regional.org.au/au//pdf/asa/2008/5804_redden.pdf. (Accessed 10 July 2016).

Rispail N. Kalo P. Kiss G.B. Ellis T.H.N. Gallardo K. Thompson R.D. Prats E. Larrainzar E. Ladrera R. Gonzalez E.M. Arrese-Igor C. Ferguson B.J. and Gresshoff P.M. (2010), Model legumes to contribute to faba bean breeding. Field Crop Res. 115, 253-269.

Robertson L.D. (1984, A note on the ILB source of Botrytis fabae resistance. In: Chapman G.P. Tarawali S.A. (eds.) Systems for Cytogenetic Analysis in Vicia Faba L. Martinus Nijhoff Dr W, Junk Publishers. Pp. 80

Rubiales D. Avila C.M. Sillero J.C. Hybl M. Narits L. Sass O. and Flores F. (2012), Identification and multi-environment validation of resistance to Ascochyta fabae in faba bean Vicia faba. Field Crop Res. 126, 165-170.

Rubiales D. Pérez-de-Luque A. Fernández-Aparico M. Sillero J.C. Román B. Kharrat M. Khalil, S. Joel D.M. and Riches C. (2006), Screening techniques and sources of resistance against parasitic weeds ingrain legumes. Euphytica. 147, 178-199.

Rubiales D. Verkleij J. Vurro M. Murdoch A.J. and Joel D.M. (2009), Parasitic plant management in sustainable agriculture. Weed Res. 49, 1-5.

Satovic Z. Avila C.M. Cruz-Izquierdo S. Díaz-Ruíz R. García-Ruíz G.M. Palomino C. Gutiérrez N. Vitale S. Ocaña-Moral S. Victoria Gutiérrez M. Cubero J.I. and Torres A.M. (2013), A reference consensus genetic map for molecular markers and economically important traits in faba bean Vicia faba L. BMC Genomics 14, 932

Siddique K.H.M. Regan K.L. Tennant D. and Thomson B.D. (2001) Water use and water use efficiency of cool season grain legumes in low rainfall Mediterranean-type environments. European J. Agron. 15, 267-280. doi:10.1016/S1161-0301(01)00106-X

Sillero J.C. Avila C.M. Moreno M.T. and Rubiales D. (2001), Identification of resistance to Ascochyta fabae in Vicia faba germplasm. Plant Breeding 120, 529-531 
Sillero J.C. Villegas-Fernandez Angel M. Thomas J. Rojas-Molina M.M. Emeran A.A. FernandezAparicio M. and Rubiales D. (2010), Faba bean breeding for disease resistance. Field Crop Res. 115, 297-307.

Solh M.B. and Pala M. (1990), Weed control in chickpea. Options Mediterr Ser Semin 9, 93-99

Stoddard F.L. Balko C. Erskine W. Khan H.R. Link W. and Sarker A. (2006), Screening techniques and sources of resistance to abiotic stresses in cool-season food legumes. Euphytica 147, 167-186. doi:10.1007/s10681-006-4723-8

Subbarao G.V. Johansen C. Slinkard A.E. Nageswara R.C. Saxena N.P. and Chauhan Y.S. (1995), Strategies for improving drought resistance in grain legumes. Critical Rev Plant Sci. 14, 469-523. doi:10.1080/07352689509701933

Temesgen T. Keneni G. Sefera T. and Jarso M. (2015), Yield stability and relationships among stability parameters in faba bean (Vicia faba L.) genotypes. The Crop J. 3, 258-269.

Tivoli B. Baranger A. Avila C.M. Banniza S. Barbetti M.C.W. Davidson J. Lindeck K. Kharrat M. Rubiales D. Sadiki M. Sillero J.C. Sweetingham M. and Muehlbauer F.J. (2006), Screening techniques and sources of resistance to foliar diseases caused by major necrotrophic fungi in grain legumes. Euphytica 147, 223-253.

Torres A.M. Avila C.M. Gutierrez N. Palomino C. Moreno M.T. and Cubero J.I. (2010), Markerassisted selection in faba bean (Vicia faba L.). Field Crop Res, 115, 243-252.

Villegas-Fernández A.M. Sillero J.C. Emeran A.A. Winkler J. Raffiot B. and Tay J. (2009) Identification and multi-environment validation of resistance to Botrytis fabae in Vicia faba. Field Crop Res. 114, 84-90.

Villegas-Fernández A.M. Sillero J.C. and Rubiales D. (2011), Screening faba bean for chocolate spot resistance: evaluation methods and effects of age of host tissue and temperature. Eur. J. Plant Pathol. 132, 443-453.

Wang J. Gan Y.T. Clarke F. and McDonald C.L. (2006), Response of chickpea yield to high temperature stress during reproductive development. Crop Sci. 46, 2171-2178

Webb A. Cottage A. Wood T. Khamassi K. Hobbs D. Gostkiewicz K. White M. Khazae H. Ali M. Street D. Duc G. Stoddard F.L. Maalouf F. Ogbonnaya F. Link W. Thomas J. and O'Sullivan D.M. (2015), A SNP-based consensus genetic map for synteny - based trait targeting in faba bean Vicia faba L. Plant Biotechnol J. 14(1), 177-85 doi: 10.1111/pbi.12371

Wery J. Silim S.N. Knights E.J. Malhotra R.S. and Cousin S. (1994), Screening techniques and sources and tolerance to extremes of moisture and air temperature in cool season food legumes. Euphytica 73, 73-83. doi:10.1007/BF00027184

Zahran H.H. (1999), Rhizobium-legume symbiosis and nitrogen fixation under severe conditions and in arid climate. Microbiology and Molecular Biology Reviews 63: 968-989. 